\title{
Positron emission tomography; viable tool in patients pre-CABG?
}

\author{
E. E. van der Wall $\cdot$ H. M. Siebelink • \\ A. J. Scholte $\cdot$ J. J. Bax
}

Received: 15 February 2010/ Accepted: 5 March 2010/Published online: 1 April 2010

(C) The Author(s) 2010. This article is published with open access at Springerlink.com

Assessment of myocardial viability and ischemia continues to be an important issue in patients with coronary artery disease and left ventricular dysfunction [1-10]. In particular in patients following a myocardial infarction and in the evaluation of patients eligible for interventional procedures such as coronary artery bypass grafting (CABG), accurate assessment of myocardial viability remains pivotal [11-14]. To assess myocardial viability, different diagnostic methods are currently performed, such as FDG/PET, MRI, SPECT, and echocardiography [15-28]. In the clinical arena, detection of myocardial viability is predominantly based on the use of nuclear techniques, which show preserved tracer uptake and metabolism in viable myocardium. FDG/PET is considered the reference standard due to its ability to differentiate dysfunctional but viable myocardium from scar formation and normal myocardium [29-38]. In patients with ischemic cardiomyopathy, CABG offers an important therapeutic option but this operative procedure is still associated with a high perioperative mortality. Although previous studies suggest a benefit from

Editorial Comment on the article Boehm et al. (doi: 10.1007/s10554-010-9585-4).

E. E. van der Wall $(\varangle) \cdot$ H. M. Siebelink ·

A. J. Scholte · J. J. Bax

Department of Cardiology, Leiden University Medical

Center, P.O. Box 9600, Leiden, Netherlands

e-mail: e.e.van_der_wall@lumc.nl revascularization for patients with defined viability by a non-invasive technique [39-44], the role of viability assessment to determine suitability for revascularization in patients with ischemic cardiomyopathy has not yet been defined.

In the current issue of the International Journal of Cardiovascular Imaging, Boehm et al. [45] evaluated the hypothesis that the use of PET imaging in the decision-making process for $\mathrm{CABG}$ will improve postoperative patient survival. The authors studied 476 patients with ischemic cardiomyopathy (left ventricular ejection fraction $<35 \%$ ) who were considered candidates for CABG. In a Standard Care Group, 298 patients underwent CABG. In a second PET-guided management group (n-178), 152 patients underwent PET-CABG; 26 patients were excluded from CABG because of lack of viability. The survival rate after 1,5 and 9.3 years was 92.0, 73.3 and 54.2\% in the PETCABG group and 88.9, 62.2 and $35.5 \%$ in the Standard Care Group, respectively $(P=0.005)$. There was a statistically significant influence on long-term survival using FDG-PET data, left ventricular function, and age over 70 years. Consequently, preoperative assessment of myocardial viability trough FDG-PET imaging identified patients who will benefit most from CABG.

The crucial finding of the present study was the significant reduction of the 30-day mortality in the PET-CABG group with 1.3 vs. $10.3 \%$ in the Standard Care group. The observed early mortality rate of $1.3 \%$ in the PET-CABG group is lower than observed in the STICH trial (Surgical Treatment for Ischemic 
Heart Failure) that reported a hospital mortality of $5 \%$ [46]. The early survival benefit of the PETCABG group persisted in the long-term as reflected by the superior survival of the PET-CABG over a 10 year follow-up. Another important message of the present study was that he criterion of scar extent alone was not sufficient for the selection process. Four patients in the PET-CABG group showed a scar tissue area $\geq 40 \%$. However, in these patients the other main viability criteria and the angiographic report supported the decision that these patients were adequate candidates for CABG.

The concept of a preoperative PET-based selection of patients who benefit mostly from CABG was examined by Haas et al. [47] who found a significant reduction in perioperative mortality in patient with defined viability. In the PARR-2 study (positron emission tomography and recovery following revascularization), patients with ischemic cardiomyopathy were randomized to management guided by FDG-PET $(n=218)$ or standard care $(n=212)$ [48]. In a subgroup of patients who adhered to PET recommendations regarding revascularization, significant survival benefits were observed. These findings are supported by the present study of Boehm et al. [45] in which every patient with sufficient viability in the PET-assisted group underwent CABG and showed significantly improved mortality rates after revascularization.

The current study did not compare FDG-PET with other imaging modalities for detection of viable myocardium such as gated SPECT imaging, MRI or low dose dobutamine echocardiography, which may have provided additional important information in the decision process for CABG. To that purpose, Siebelink et al. [49] sought to prospectively compare nitrogen-13 (13 N)ammonia/18FDG-PET guided management with stress/ rest $99 \mathrm{mTc}$-sestamibi SPECT-guided management in 103 patients considered for revascularization with left ventricular wall motion abnormalities and suspicion of jeopardized myocardium. In terms of cardiac event-free survival, no differences between PET and SPECT were observed (11 vs. 13 cardiac events for PET and SPECT, respectively). No differences in patient management or cardiac event-free survival were demonstrated between management based on $13 \mathrm{~N}$-ammonia/18FDG PET and that based on stress/rest $99 \mathrm{mTc}$-sestamibi SPECT imaging. Both techniques may be used for viabilityguided management of patients considered for revascularization with suspicion of jeopardized myocardium.
To summarize, the study by Boehm et al. [45] reemphasizes the need for accurate preoperative viability imaging in patients with ischemic cardiomyopathy. Viability guided assessment may result in a significant reduction of peri-operative mortality rates after $\mathrm{CABG}$. However, the question of viability assessment to determine suitability for revascularization is still not fully resolved and an optimal diagnostic protocol in patients with ischemic cardiomyopathy has to be defined. Consequently, larger studies are necessary to further evaluate the impact of preoperative viability assessment in this high-risk group of patients.

Open Access This article is distributed under the terms of the Creative Commons Attribution Noncommercial License which permits any noncommercial use, distribution, and reproduction in any medium, provided the original author(s) and source are credited.

\section{References}

1. Bax JJ, Lamb H, Dibbets P, Pelikan H et al (2000) Comparison of gated single-photon emission computed tomography with magnetic resonance imaging for evaluation of left ventricular function in ischemic cardiomyopathy. Am J Cardiol 86:1299-1305

2. Bax JJ, van der Wall EE, Harbinson M (2004) Radionuclide techniques for the assessment of myocardial viability and hibernation. Heart 90(Suppl 5):v26-33

3. van der Wall EE, Heidendal GA, den Hollander W, Westera G, Roos JP (1980) I-123 labeled hexadecenoic acid in comparison with Thallium-201 for myocardial imaging in coronary heart disease. A preliminary study. Eur J Nucl Med 5:401-405

4. Thygesen K, Alpert JS, White HD, Joint ESC/ACCF/AHA/ WHF Task Force for the Redefinition of Myocardial Infarction (2007) Universal definition of myocardial infarction. Circulation 116:2634-2653

5. Slart RH, Bax JJ, Sluiter WJ, van Veldhuisen DJ, Jager PL (2004) Added value of attenuation-corrected Tc-99m tetrofosmin SPECT for the detection of myocardial viability: comparison with FDG SPECT. J Nucl Cardiol 11:689-696

6. Bavelaar-Croon CD, Pauwels EK, van der Wall EE (2001) Gated single-photon emission computed tomographic myocardial imaging: a new tool in clinical cardiology. Am Heart J 14:383-390

7. Bavelaar-Croon CD, Kayser HW, van der Wall EE et al (2000) Left ventricular function: correlation of quantitative gated SPECT and MR imaging over a wide range of values. Radiology 217:572-575

8. Sciagrà R, Leoncini M (2005) Gated single-photon emission computed tomography. The present-day "one-stopshop" for cardiac imaging. Q J Nucl Med Mol Imaging 49:19-29 
9. America YG, Bax JJ, Dibbets-Schneider P, Pauwels EK, Van der Wall EE (2005) Evaluation of the Quantitative Gated SPECT (QGS) software program in the presence of large perfusion defects. Int $\mathbf{J}$ Cardiovasc Imaging 21:519-529

10. van Eck-Smit BL, van der Wall EE, Kuijper AF, Zwinderman AH, Pauwels EK (1993) Immediate thallium-201 reinjection following stress imaging: a time-saving approach for detection of myocardial viability. J Nucl Med 34:737-743

11. Groutars RG, Verzijlbergen JF, Tiel-van Buul MM et al (2003) The accuracy of 1-day dual-isotope myocardial SPECT in a population with high prevalence of coronary artery disease. Int J Cardiovasc Imaging 19:229-238

12. van der Wall EE, den Hollander W, Heidendal GA, Westera G, Majid PA, Roos JP (1981) Dynamic myocardial scintigraphy with $123 \mathrm{I}$-labeled free fatty acids in patients with myocardial infarction. Eur J Nucl Med 6:383-389

13. van der Hoeven BL, Pires NM, Warda HM et al (2005) Drug-eluting stents: results, promises and problems. Int $\mathbf{J}$ Cardiol 99:9-17

14. Langerak SE, Vliegen HW, de Roos A et al (2002) Detection of vein graft disease using high-resolution magnetic resonance angiography. Circulation 105:328-333

15. van der Wall EE, van Dijkman PR, de Roos A et al (1990) Diagnostic significance of gadolinium-DTPA (diethylenetriamine penta-acetic acid) enhanced magnetic resonance imaging in thrombolytic treatment for acute myocardial infarction: its potential in assessing reperfusion. Br Heart J 63:12-17

16. van Dijkman PR, van der Wall EE, de Roos A et al (1991) Acute, subacute, and chronic myocardial infarction: quantitative analysis of gadolinium-enhanced MR images. Radiology 180:147-151

17. de Roos A, Matheijssen NA, Doornbos J, van Dijkman PR, van Voorthuisen AE, van der Wall EE (1990) Myocardial infarct size after reperfusion therapy: assessment with GdDTPA-enhanced MR imaging. Radiology 176:517-521

18. de Roos A, Matheijssen NA, Doornbos J, van Dijkman PR, van Rugge PR, van der Wall EE (1991) Myocardial infarct sizing and assessment of reperfusion by magnetic resonance imaging: a review. Int J Card Imaging 7:133-138

19. Vliegen HW, Doornbos J, de Roos A, Jukema JW, Bekedam MA, van der Wall EE (1997) Value of fast gradient echo magnetic resonance angiography as an adjunct to coronary arteriography in detecting and confirming the course of clinically significant coronary artery anomalies. Am J Cardiol 79:773-776

20. Hoogendoorn LI, Pattynama PM, Buis B, van der Geest RJ, van der Wall EE, de Roos A (1995) Noninvasive evaluation of aortocoronary bypass grafts with magnetic resonance flow mapping. Am J Cardiol 75:845-848

21. van Rugge FP, Holman ER, van der Wall EE, de Roos A, van der Laarse A, Bruschke AV (1993) Quantitation of global and regional left ventricular function by cine magnetic resonance imaging during dobutamine stress in normal human subjects. Eur Heart J 14:456-463

22. van der Geest RJ, de Roos A, van der Wall EE, Reiber JH (1997) Quantitative analysis of cardiovascular MR images. Int J Card Imaging 13:247-258

23. van der Geest RJ, Niezen RA, van der Wall EE, de Roos A, Reiber JH (1998) Automated measurement of volume flow in the ascending aorta using MR velocity maps: evaluation of inter- and intraobserver variability in healthy volunteers. J Comput Assist Tomogr 22:904-911

24. van Rugge FP, van der Wall EE, van Dijkman PR, Louwerenburg HW, de Roos A, Bruschke AV (1992) Usefulness of ultrafast magnetic resonance imaging in healed myocardial infarction. Am J Cardiol 70:1233-1237

25. Holman ER, van Jonbergen HP, van Dijkman PR, van der Laarse A, de Roos A, van der Wall EE (1993) Comparison of magnetic resonance imaging studies with enzymatic indexes of myocardial necrosis for quantification of myocardial infarct size. Am J Cardiol 71:1036-1040

26. Bleeker GB, Schalij MJ, Holman ER, Steendijk P, van der Wall EE, Bax JJ (2006) Cardiac resynchronization therapy in patients with systolic left ventricular dysfunction and symptoms of mild heart failure secondary to ischemic or nonischemic cardiomyopathy. Am J Cardiol 98: 230-235

27. Bleeker GB, Bax JJ, Fung JW et al (2006) Clinical versus echocardiographic parameters to assess response to cardiac resynchronization therapy. Am J Cardiol 97:260-263

28. Tulevski II, Hirsch A, Sanson BJ et al (2001) Increased brain natriuretic peptide as a marker for right ventricular dysfunction in acute pulmonary embolism. Thromb Haemost 86:1193-1196

29. Pluim BM, Lamb HJ, Kayser HW, Leujes F et al (1998) Functional and metabolic evaluation of the athlete's heart by magnetic resonance imaging and dobutamine stress magnetic resonance spectroscopy. Circulation 97:666-672

30. Pluim BM, Beyerbacht HP, Chin JC et al (1997) Comparison of echocardiography with magnetic resonance imaging in the assessment of the athlete's heart. Eur Heart J 18:1505-1513

31. Pluim BM, Chin JC, De Roos A et al (1996) Cardiac anatomy, function and metabolism in elite cyclists assessed by magnetic resonance imaging and spectroscopy. Eur Heart J 17:1271-1278

32. Braun S, van der Wall EE, Emanuelsson S, Kobrin I (1996) Effects of a new calcium antagonist, mibefradil (Ro 405967), on silent ischemia in patients with stable chronic angina pectoris: a multicenter placebo-controlled study. The mibefradil international study group. J Am Coll Cardiol 27:317-322

33. Portegies MC, Schmitt R, Kraaij CJ et al (1991) Lack of negative inotropic effects of the new calcium antagonist Ro 40-5967 in patients with stable angina pectoris. J Cardiovasc Pharmacol 18:746-751

34. de Nooijer R, Verkleij CJ, von der Thüsen JH et al (2006) Lesional overexpression of matrix metalloproteinase-9 promotes intraplaque hemorrhage in advanced lesions but not at earlier stages of atherogenesis. Arterioscler Thromb Vasc Biol 26:340-346

35. van der Laarse A, Kerkhof PL, Vermeer F et al (1988) Relation between infarct size and left ventricular performance assessed in patients with first acute myocardial infarction randomized to intracoronary thrombolytic therapy or to conventional treatment. Am J Cardiol 61:1-7

36. Bakx AL, van der Wall EE, Braun S, Emanuelsson $\mathrm{H}$, Bruschke AV, Kobrin I (1995) Effects of the new calcium antagonist mibefradil (Ro 40-5967) on exercise duration in patients with chronic stable angina pectoris: a multicenter, 
placebo-controlled study. Ro 40-5967 International Study Group. Am Heart J 130:748-757

37. van Rugge FP, Boreel JJ, van der Wall EE et al (1991) Cardiac first-pass and myocardial perfusion in normal subjects assessed by sub-second Gd-DTPA enhanced MR imaging. J Comput Assist Tomogr 15:959-965

38. Nijveldt R, Beek AM, Hirsch A et al (2008) 'No-reflow' after acute myocardial infarction: direct visualisation of microvascular obstruction by gadolinium-enhanced CMR. Neth Heart J 16:179-181

39. Bax JJ, Visser FC, van Lingen A, Cornel JH, Fioretti PM, van der Wall EE (1997) Metabolic imaging using F18fluorodeoxyglucose to assess myocardial viability. Int $\mathrm{J}$ Card Imaging 13:145-155

40. Underwood SR, Bax JJ, vom Dahl J et al (2004) Study Group of the European Society of Cardiology. Imaging techniques for the assessment of myocardial hibernation. Report of a Study Group of the European Society of Cardiology. Eur Heart J 25:815-836

41. Slart RH, Bax JJ, de Boer J et al (2005) Comparison of 99mTc-sestamibi/18FDG DISA SPECT with PET for the detection of viability in patients with coronary artery disease and left ventricular dysfunction. Eur J Nucl Med Mol Imaging 32:972-979

42. Slart RH, Bax JJ, van Veldhuisen DJ, van der Wall EE, Dierckx RA, Jager PL (2006) Imaging techniques in nuclear cardiology for the assessment of myocardial viability. Int J Cardiovasc Imaging 22:63-80

43. Slart RH, Bax JJ, van Veldhuisen DJ et al (2006) Prediction of functional recovery after revascularization in patients with chronic ischaemic left ventricular dysfunction: head-to-head comparison between 99mTcsestamibi/18F-FDG DISA SPECT and $13 \mathrm{~N}$-ammonia/ 18F-FDG PET. Eur J Nucl Med Mol Imaging 33:716-723

44. Tio RA, Dabeshlim A, Siebelink HM et al (2009) Comparison between the prognostic value of left ventricular function and myocardial perfusion reserve in patients with ischemic heart disease. J Nucl Med 50:214-219

45. Boehm J, Haas F, Bauernschmitt R et al (2010) Impact of preoperative positron emission tomography in patients with severely impaired LV-function undergoing surgical revascularization. Int J Cardiovasc Imaging [Epub ahead of print]

46. Haas F, Haehnel CJ, Picker W et al (1997) Preoperative positron emission tomographic viability assessment and perioperative and postoperative risk in patients with advanced ischemic heart disease. J Am Coll Cardiol 30:1693-1700

47. Jones RH, Velazquez EJ, Michler RE et al (2009) Coronary bypass surgery with or without surgical ventricular reconstruction. N Engl J Med 360:1705-1717

48. Beanlands RS, Nichol G, Huszti E et al (2007) F-18-fluorodeoxyglucose positron emission tomography imagingassisted management of patients with severe left ventricular dysfunction and suspected coronary disease: a randomized, controlled trial (PARR-2). J Am Coll Cardiol 50:2002-2012

49. Siebelink HM, Blanksma PK, Crijns HJ et al (2001) No difference in cardiac event-free survival between positron emission tomography-guided and single-photon emission computed tomography-guided patient management: a prospective, randomized comparison of patients with suspicion of jeopardized myocardium. J Am Coll Cardiol 37: 81-88 